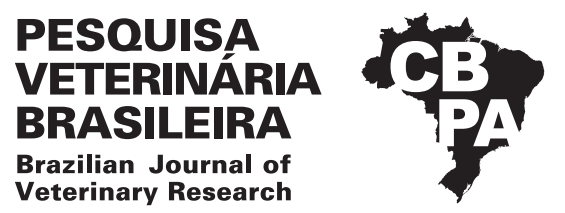

Pesq. Vet. Bras. 39(3):179-185, March 2019 DOI: 10.1590/1678-5150-PVB-6201

Original Article

ISSN 0100-736X (Print)

Livestock Diseases

ISSN 1678-5150 (Online)

\title{
Bovine rabies: economic loss and its mitigation through antirabies vaccination ${ }^{1}$
}

\author{
Ana Karla M. Mello², Ricardo C. Brumatti², Danielle A. Neves ${ }^{3}$, \\ Lilian O.B. Alcântara ${ }^{3}$, Fábio S. Araújo ${ }^{3}$, Alberto O. Gaspar² \\ and Ricardo A.A. Lemos ${ }^{4 *}$ (D)
}

\begin{abstract}
Mello A.K.M., Brumatti R.C., Neves D.A., Alcântara L.O.B., Araújo F.S., Gaspar A.O \& Lemos R.A.A. 2019. Bovine rabies: economic loss and its mitigation through antirabies vaccination. Pesquisa Veterinária Brasileira 39(3):179-185. Laboratório de Patologia Animal, Faculdade de Medicina Veterinária e Zootecnia, Universidade Federal de Mato Grosso do Sul, Avenida Senador Filinto Muller 2443, Jd. Monte Alegre, Campo Grande, MS 79074-460, Brazil.E-mail: lap.famez@ufms.br

Rabies is among the most common neurological disease in cattle in Brazil, causing significant economic losses. Data on the economic impact of rabies in livestock are available in several countries. However, in Brazil, these data focus mainly on the public health point o view, emphasizing the costs related to the prevention of rabies in humans, in dogs, or wildlife. Specific studies carried out in different regions of Brazil indicate critical economic losses caused by rabies in cattle in this country. However, the studies on the losses caused by the disease in cattle lack a detailed analysis of the affected rural properties based on data from official disease control agencies. The objective of this work was to evaluate the economic impact of bovine rabies, and its mitigation through antirabies vaccination in rural properties in Mato Grosso do Sul, Midwestern Brazil.
\end{abstract}

INDEX TERMS: Bovine rabies, economic loss, antirabies vaccination, cattle, clinics.

RESUMO.- [Raiva em bovinos: perdas econômicas e sua mitigação através da vacinação antirrábica.] A raiva é uma das doenças neurológicas mais comuns em bovinos no Brasil, causando perdas econômicas significativas. Dados sobre o impacto econômico da raiva em bovinos de vários países estão disponíveis. No entanto, no Brasil, esses dados enfocam principalmente o ponto de vista de saúde pública, enfatizando os custos relacionados à prevenção da raiva em humanos, em cães ou animais silvestres. Estudos pontuais realizados em diferentes regiões do Brasil indicam perdas econômicas importantes causadas pela raiva em bovinos no

\footnotetext{
${ }^{1}$ Received on November 19, 2018.

Accepted for publication on December 6, 2018.

Part of the Doctoral Dissertation of the first author.

${ }^{2}$ Postgraduate Program in Animal Science, Faculdade de Medicina Veterinária e Zootecnia (FAMEZ), Universidade Federal de Mato Grosso do Sul (UFMS), Av. Senador Felinto Muller 2443, Jd. Monte Alegre, Campo Grande, MS 79074-460, Brazil.

${ }^{3}$ Divisão de Defesa Sanitária Animal, Agência Estadual de Defesa Sanitária Animal e Vegetal (IAGRO), Av. Senador Filinto Muller 1146, Campo Grande, MS 79074-902.

${ }^{4}$ Laboratório de Anatomia Patológica, Faculdade de Medicina Veterinária e Zootecnia (FAMEZ), Universidade Federal de Mato Grosso do Sul (UFMS), Av. Senador Felinto Muller 2443, Jd. Monte Alegre, Campo Grande, MS 79074460. *Corresponding author: lap.famez@ufms.br
}

país. No entanto, os estudos sobre as perdas causadas pela doença em bovinos carecem de uma análise detalhada das propriedades rurais afetadas com base em dados das agências oficiais de controle de doenças. 0 objetivo deste trabalho foi avaliar o impacto econômico da raiva bovina e sua mitigação através da vacinação antirrábica em propriedades rurais de Mato Grosso do Sul, no Centro-Oeste do Brasil.

TERMOS DE INDEXAÇÃO: Raiva em bovinos, perdas econômicas, vacinação antirrábica, bovinos, clínica.

\section{INTRODUCTION}

Rabies is a neurological disease caused by a Lyssavirus of the Rhabdoviridae familyand can affect all mammals (Swanepoel 2004). In cattle, it is an acute disease, invariably fatal, transmitted through the saliva of the vampire bat Desmodus rotundus (Barros et al. 2006). It is one of the most prevalent neurological diseases in ruminants (Barros et al. 2006), causing significant economic losses, especially for developing countries (King \& Turner 1993, Rupprecht et al. 2002, Lima et al. 2005).

Although the economic significance of rabies in cattle in Brazil can be inferred by studies on the prevalence of the disease in different regions of the country (Langohr et al. 2003, 
Marcolongo-Pereira et al. 2011, Ribas et al. 2013), there are no detailed studies on the economic losses caused by the disease. An estimation of these losses is hampered by the difficulty in obtaining reliable data on the occurrence of the disease (Kotait et al. 1998, Braga et al. 2014, Taylor \& Knopf 2015). The Brazilian National Herbivore Rabies Control Program (PNCRH), implemented a solid system of information and surveillance in areas or properties at risk, closely following the outbreaks of the disease. It aims to effectively control rabies in domestic herbivores through strategic vaccination of the susceptible species and control of the vampire bat. The data generated by the PNCRH are an essential source for the study of the economic impact caused by rabies in cattle in Brazil.

In 1988 The World Health Organization (WHO) recognized the lack of data on the economic significance of rabies and suggested the development of a model that would be the basis for determining the costs required for controlling the disease, but this model did not appear in the literature (Meltzer \& Rupprecht 1998).

Studies on the economic impact of rabies are conducted in several countries, but the focus of these studies is mainly on public health, emphasizing the costs related to the prevention of human (Shwiff et al. 2007, Dhankhar et al. 2008, Anyiam et al. 2017), canine or wild animals (Knobel et al. 2005, Sterner et al. 2009, Hampson et al. 2015) rabies. Wild stock is a potential transmitter of the disease to humans (Swanepoel 2004). Particularly concerning bovine rabies, a detailed study was conducted in Mexico (Anderson et al. 2012) analyzing and comparing the efficiency of two methods of rabies control: vampire bat control and vaccination of cattle at risk.

However, studies analyzing losses occurring on rural properties, based on data from an official disease control program, were not found in the literature. Analysis of the economic impact of diseases is relevant to highlight the importance of agricultural defense policies. It also contributes to identifying priority health policies and also to support decision making by rural producers.

Using data provided by PNCRH, this study was aimed to evaluate the economic impact of bovine rabies on rural properties of Mato Grosso do Sul (MS) and the mitigation of this impact by antirabies vaccination.

\section{MATERIALS AND METHODS}

A retrospective study was carried out consulting the data contained in the initial formulary (FORM IN) on bovine rabies of the State Agency of Animal and Plant Health Protection of MS (IAGRO). The study covered all state area from 2010 to 2016 . The following data were analyzed: size of the property, its location, the notifications of rabies occurrence, the number of bovine in the herd, the number of cattle deaths and the herd rabies vaccination status.

For the calculations, the criterion for considering a rabies case was any sick or dead cattle from a herd with an ongoing outbreak with a definite diagnosis of rabies in one or more components of the herd. Tests accepted for detecting a positive case were direct fluorescent antibody test (dFA) and intracerebral inoculation of suckling mice (IISM), following the Brazilian Herbivore Rabies Control Manual (BHRCM) (Brasil 2009). An event was considered an outbreak of bovine rabies there was the death of more than one bovine per herd.

The market value of the $\mathrm{kg}$ of beef was used for the calculation of the stockholders' equity considering the number of cattle in the property studied. The calculations were made using the average of the prices reported by CEPEA/ESALQ and BM\&F Bovespa (CEPEA 2017), for July 2017, which is the official source for the price of the kilo of fat steers in Brazil, which was converted to dollars using the Brazilian Central Bank quotations for the same period.

Morbidity (morb.) was calculated by the following formula (Thrusfield 2004):

$$
\text { Morb. }=\left(\frac{\text { Total of sick cattle }}{\text { Total cattle population at risk }}\right) \times 100
$$

The patrimony estimated (PEs) for each property was based on the number of cattle in the herd. The value of each cattle category was estimated by the value paid per kg of beef multiplied by the estimated weight of individual cattle in each category multiplied for the yield of carcass:

$$
\text { PEs }=(\text { N.cattle }) \times(\text { E. weight } \times \text { E.Y.C })) \times U S \$ / \mathrm{kg}
$$

Where N.cattle $=$ number of cattle, E.weight $=$ Estimated weight , and E.Y.C = Estimated yield of carcass.

The estimated total equity was calculated by the sum of the estimated equity in each cattle category. The economic losses per category (EconLCat) were estimated by the sum of the dead animals in the category multiplied by the estimated weight and estimated yield, multiplied by the amount paid per $\mathrm{kg}$ of beef according to the following formula:

$$
\text { EconLCat }=\left(\sum \text { head cat } \times(\text { E. weight } \times \text { EYC })\right) \times \text { US\$ } / \mathrm{kg}
$$

Where head cat=heads per category, E. weight = Estimated weight, and $E Y C=$ Estimated yield of carcass.

The total economic loss was calculated using the sum of the economic losses per category. For the calculation of the dose of rabies vaccine, prices practiced in the resales market of the Capital of MS were surveyed. The cost of vaccination by category of cattle was calculated using the total number of cattle per category multiplied by the number of times they were vaccinated and then multiplied by the amount paid per vaccine dose. Three strategic vaccinations were considered, one at three months, one booster after 30 days and annual revaccinations, according to the BHRCM. The total cost of vaccination was calculated by adding up the cost of vaccination in the different cattle categories.

$$
\text { Cvac } / \text { cat. }=\left(\sum \text { head catx numbers of vaccine doses }\right) \times \text { US\$ } / \text { dose }
$$

Where $C v a c=$ Cost of vaccination, head $c a t=$ heads per category.

The following formula estimated the relationship between the cost of herd vaccination and the economic loss caused by rabies-induced death in cattle:

$$
\text { C.Vac. } / \text { P.Econ }=((\text { TVacC }) /(\text { TEconL })) \times 100
$$

Where $C v a c=$ Cost of vaccination, $T$ vacC $\operatorname{cost}, T E \operatorname{con} L=$ total economic loss.

The resultant values were analyzed to obtain the descriptive statistics with the determination of the histograms of occurrences.

\section{RESULTS}

From January 2010 to December 2016, there were 52 outbreaks of bovine rabies in 23 out the entire 79 municipalities forming the state of Mato Grosso do Sul (Fig.1), with a total of 305 deaths of rabid cattle. The size cattle herd of Mato 


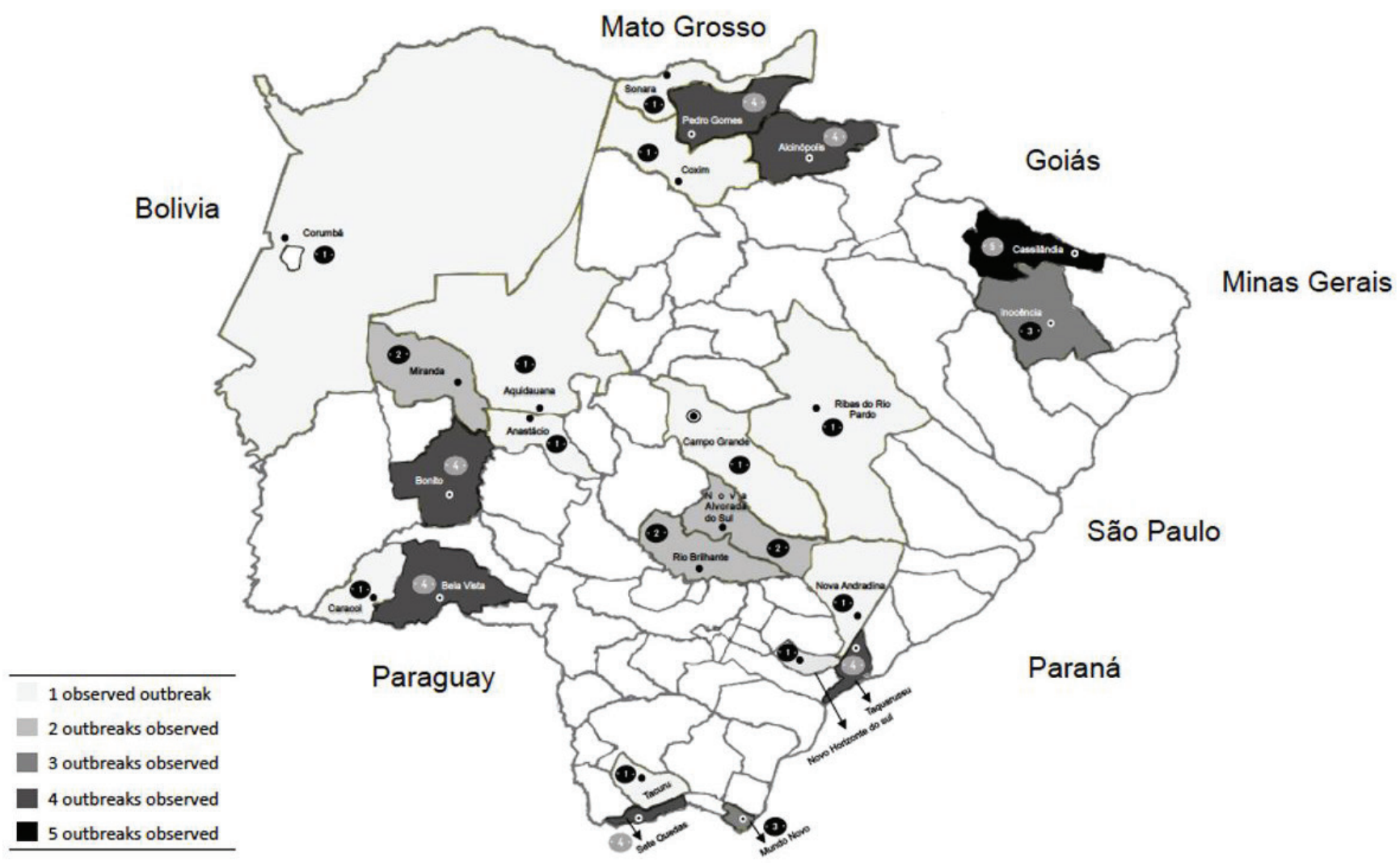

Fig.1. Map of Mato Grosso do Sul highlighting the municipalities where one or more rabies outbreak occurred from 2010 to 2016 . The number of outbreaks for each municipality is noted.

Grosso do Sul is of 21.8 million bovines (IBGE 2016), of which 9.50 million (43.57\% of the herd of the state of MS) are in areas where rabies occurs and therefore are exposed to the risk of bovine rabies. Epidemiological data on outbreaks are shown in Table 1.

Cases of bovine rabies were observed in large and small farms, with herds consisting of 10 to 6,210 cattle. The estimated value of the assets ranged from US $\$ 4,307.00$ to US $\$ 3,005,948.00$. The average value of the equity was estimated at US\$ $402,528.00$. The total value of the assets of properties that had outbreaks of rabies was valued at approximately US\$20,931,466.00.

In 28 properties, the number of deaths per herd varied from 1-2 cattle, in ten the number was 3-5 cattle and in fourteen properties the number of dead cattle died was above six. The morbidity varied widely from $0.04-20 \%$; the lethality was $100 \%$.

In 39 properties, the estimated patrimony was up to US $\$ 500,000.00$; other thirteen properties presented values above that (Fig.2), indicating that most of the properties fit as small and medium rural properties. In 47 properties, the estimated economic loss was less than US $\$ 5,000.00$; the others sustained losses heavier than this (Fig.3).

Currently, MS has 12 municipalities where vaccination is mandatory, namely: Aquidauana, Anastácio, Corumbá, Miranda, Bonito, Coxim, Corguinho, Bodoquena, Rio Verde de Mato Grosso, Rio Negro, Jardim, and Ladário (Fig.1). The criterion adopted for the inclusion of a municipality in an

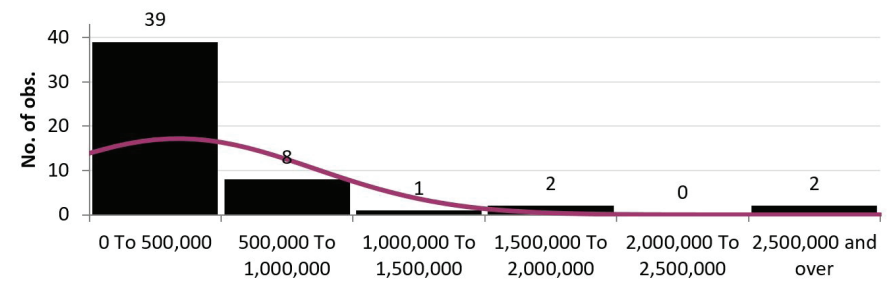

Fig.2. Histogram of the distribution of the values in US dollars of estimated stockholders' equity of the rural properties where outbreaks of bovine rabies occurred.

area of obligatory vaccination is in the number of outbreaks that occurred historically in this municipality (Brasil 2009).

The average dose price of anti-rabies vaccine practiced in MS in July 2017 was $\$ 0.12$. The estimated amounts spent on vaccination ranged from US $\$ 2.00$ to US $\$ 1,437.00$ per property, depending on the number of cattle. In 45 properties this cost was less than US\$200.00. The average cost of vaccination was $\$ 148.00$. Total vaccination expenditures of all herds at all properties where outbreaks of rabies were observed were US\$ 7,716.12 (Fig.4).

The ratio of the estimated cost of rabies vaccination of the entire herd to the economic loss per property was, on average, 9.74\%. In 37 properties, this relation was less than $10 \%$ (Fig.5). The relation between the total cost of vaccination and the total economic loss, adding up to all the properties studied, was $5.8 \%$. 
Table 1. Epidemiological data on bovine rabies outbreaks in Mato Grosso do Sul, from 2010 to 2016

\begin{tabular}{|c|c|c|c|c|c|c|}
\hline Outbreak & Month & Year & Municipality & $\begin{array}{c}\text { Number of cattle in the } \\
\text { herd }\end{array}$ & Number of deaths & $\begin{array}{c}\text { Morbidity } \\
(\%)\end{array}$ \\
\hline 1 & January & 2010 & Alcinópolis & 5,970 & 76 & 1.27 \\
\hline 2 & February & 2010 & Pedro Gomes & 1,609 & 6 & 0.37 \\
\hline 3 & March & 2010 & Alcinópolis & 584 & 2 & 0.34 \\
\hline 4 & March & 2010 & Alcinópolis & 39 & 3 & 7.69 \\
\hline 5 & August & 2010 & Alcinópolis & 338 & 2 & 0.59 \\
\hline 6 & December & 2010 & Taquarussu & 37 & 1 & 2.7 \\
\hline 7 & December & 2010 & Taquarussu & 150 & 2 & 1.33 \\
\hline 8 & December & 2010 & Taquarussu & 85 & 1 & 1.18 \\
\hline 9 & March & 2011 & Aquidauana & 996 & 6 & 0.6 \\
\hline 10 & March & 2011 & Rio Brilhante & 1,282 & 5 & 0.39 \\
\hline 11 & February & 2011 & Nova Alvorada do Sul & 499 & 2 & 0.4 \\
\hline 12 & March & 2011 & Cassilândia & 234 & 6 & 2.56 \\
\hline 13 & March & 2011 & Cassilândia & 258 & 1 & 0.39 \\
\hline 14 & October & 2011 & Cassilândia & 182 & 1 & 0.55 \\
\hline 15 & October & 2011 & Cassilândia & 488 & 1 & 0.2 \\
\hline 16 & October & 2011 & Cassilândia & 57 & 1 & 1.75 \\
\hline 17 & December & 2011 & Nova Alvorada do Sul & 441 & 3 & 0.68 \\
\hline 18 & March & 2012 & Inocência & 419 & 2 & 0.47 \\
\hline 19 & May & 2012 & Anastácio & 903 & 12 & 1.33 \\
\hline 20 & June & 2012 & Miranda & 421 & 3 & 0.71 \\
\hline 21 & October & 2012 & Miranda & 1430 & 1 & 0.07 \\
\hline 22 & January & 2013 & Caracol & 572 & 5 & 0.87 \\
\hline 23 & May & 2013 & Inocência & 636 & 4 & 0.63 \\
\hline 24 & May & 2013 & Mundo Novo & 21 & 1 & 4.76 \\
\hline 25 & June & 2013 & Mundo Novo & 22 & 1 & 4.55 \\
\hline 26 & June & 2013 & Mundo Novo & 20 & 1 & 10 \\
\hline 27 & September & 2013 & Sonora & 5,297 & 33 & 0.62 \\
\hline 28 & February & 2014 & Bela Vista & 2,482 & 1 & 0.04 \\
\hline 29 & March & 2014 & Taquarussu & 10 & 2 & 20 \\
\hline 30 & April & 2014 & Bonito & 1,388 & 6 & 0.43 \\
\hline 31 & April & 2014 & Coxim & 19 & 2 & 10.53 \\
\hline 32 & April & 2014 & Bonito & 1,024 & 10 & 0.97 \\
\hline 33 & May & 2014 & Bonito & 318 & 4 & 1.26 \\
\hline 34 & May & 2014 & Bonito & 18 & 2 & 11.11 \\
\hline 35 & June & 2014 & Sete Quedas & 1,196 & 3 & 0.25 \\
\hline 36 & June & 2014 & Bela Vista & 533 & 9 & 1.69 \\
\hline 37 & July & 2014 & Sete Quedas & 1,106 & 2 & 0.18 \\
\hline 38 & June & 2014 & Inocência & 139 & 3 & 2.16 \\
\hline 39 & July & 2014 & Pedro Gomes & 595 & 2 & 0.34 \\
\hline 40 & September & 2014 & Sete Quedas & 1,321 & 1 & 0.08 \\
\hline 41 & October & 2014 & Tacuru & 430 & 7 & 1.63 \\
\hline 42 & October & 2014 & Sete Quedas & 731 & 2 & 0.27 \\
\hline 43 & November & 2014 & Bela Vista & 231 & 2 & 0.87 \\
\hline 44 & May & 2015 & Rio Brilhante & 68 & 2 & 2.94 \\
\hline 45 & April & 2015 & Pedro Gomes & 661 & 9 & 1.36 \\
\hline 46 & June & 2015 & Bela Vista & 1,200 & 33 & 2.75 \\
\hline 47 & July & 2015 & Ribas do Rio Pardo & 577 & 2 & 0.35 \\
\hline 48 & July & 2015 & Campo Grande & 150 & 1 & 0.67 \\
\hline 49 & March & 2015 & Corumbá & 27 & 3 & 11.11 \\
\hline 50 & March & 2015 & Pedro Gomes & 150 & 1 & 0.67 \\
\hline 51 & April & 2016 & Nova Andradina & 4,268 & 6 & 0.14 \\
\hline 52 & September & 2016 & Novo Horizonte do Sul & 6,210 & 8 & 0.13 \\
\hline TOTAL & & & & 47,842 & 305 & \\
\hline
\end{tabular}




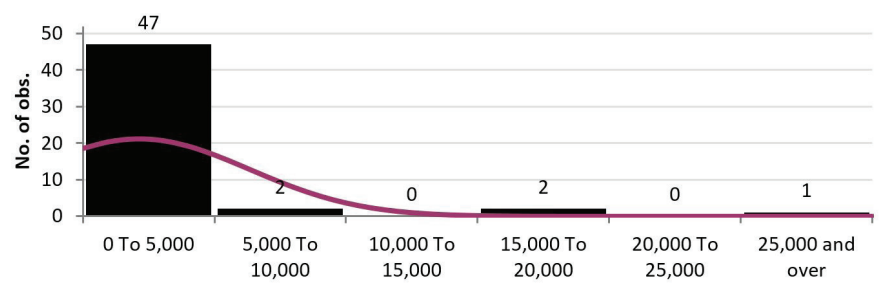

Fig3. Histogram of the distribution of the values in US dollars of estimated economic losses of the rural properties where outbreaks of bovine rabies occurred.

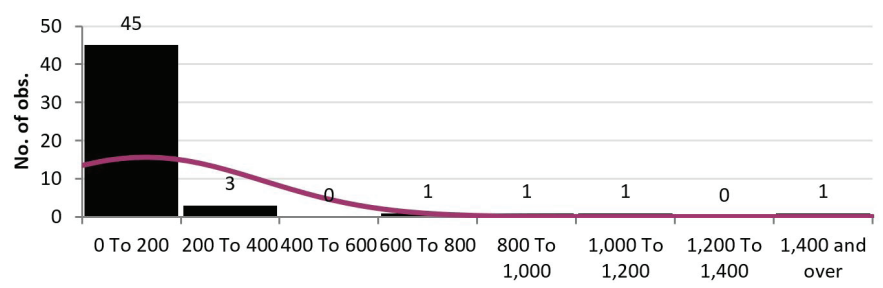

Fig.4. Histogram of the distribution of the values in US dollars of the estimated cost with vaccination in rural properties where outbreaks of bovine rabies occurred.

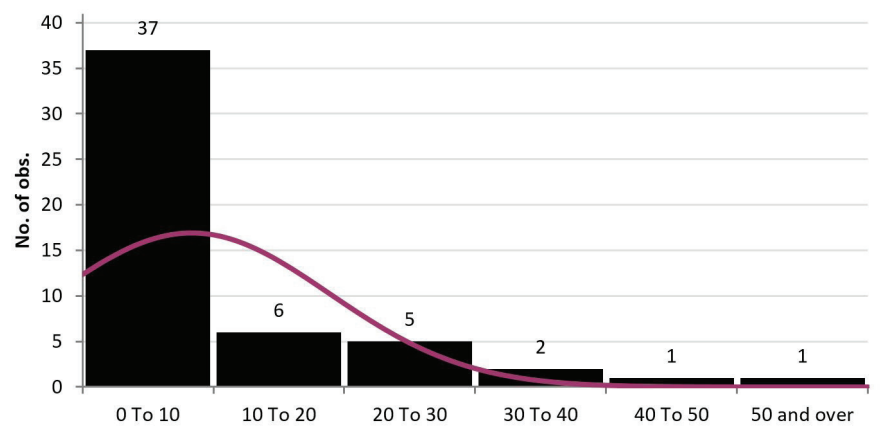

Fig.5. Histogram of distribution of the values of the ratios (\%) between estimated cost with vaccination and estimated economic losses for rural properties where outbreaks of bovine rabies occurred.

\section{DISCUSSION}

The results of the present study demonstrate that rabies is a frequent disease in bovines in MS occurring in every year of the studied period. The area where the outbreaks were diagnosed is where of the cattle population of MS is concentrated (IBGE 2016). It is noteworthy that of the 23 municipalities with the occurrence of bovine rabies, 12 are mandatory anti-rabies vaccination zone (IBGE 2016). The persistence in the occurrence of outbreaks in this zone indicates a failure in the immunization process of the cattle.

In five of the seven years studied, the number of outbreaks was 6-9, with one peak and significant declines in the number of outbreaks in one and two years respectively. The highest number of outbreaks diagnosed in certain years can be attributed to a more effective surveillance in those years (Brasil 2009, Oliveira et al. 2013). The decline is considered a standard pattern in rabies epidemiology (Mori \& Lemos 1998, Teixeira et al. 2008) and it is attributed to cyclic dynamics of vampire bat population.
When analyzed in their entirety, the economic losses of the reported outbreaks are below US $\$ 5,000.00$. In a few outbreaks, the losses were between US\$ $15,000.00$ and US\$25,000.00. These data demonstrate the importance of analyzing stratified losses by focusing on the occurrences of each property. Data evaluated without considering the morbidity ratios of each outbreak do not reflect the potential risk for each property and may convey the wrong message that the disease poses no risk of significant economic losses for individual farmers.

This misinterpretation is apparent when analyzing the total herd of farms with rabies outbreaks: properties with the lowest number of cattle had the highest morbidity ratios.

Lethality is invariably $100 \%$; in order to calculate the losses, all sick cattle at the time of data collection should be considered as a loss.

The data presented here markedly differ from those of other rabies Brazilian studies (Sanches et al. 2000, Lemos 2005, Lima et al. 2005). Some authors mention that 30,000 to 40,000 cattle die each year of rabies in Brazil (Silva et al. 2000, Heinemann et al. 2002). It should be noted, however, that these studies are not based on reliable surveys, and the authors mention lack of accurate official data on deaths caused by bovine rabies.

The difficulty in obtaining accurate data on the losses caused by bovine rabies in Brazil is mentioned by several authors (Lemos 2005, Oliveira et al. 2013, Andrade et al. 2014). Studies based on surveys involving historical series reveal great variation according to the region of the country where the study was done. In a thirty-five-year retrospective study conducted in the Central region of Rio Grande do Sul, 151 cases of bovine rabies were diagnosed, in a total of 6,021 examined materials (49.5\%) in the routine diagnostic service. A retrospective 16-year study conducted in the state of Paraná (Dognani et al. 2016) describes the occurrence of $2,331(30.6 \%)$ cases in a total of 7,627 bovine samples examined. Another 16-year retrospective study was conducted in Rio Grande do Sul (Teixeira et al. 2008), in which 670 cases of rabies were diagnosed within a total of 1,729 samples (38.7\%). In Minas Gerais (Silva et al. 2001), in a period of 7 years, 1,540 cases of rabies were found out of a total of 3,073 samples examined $(50.1 \%)$,

Despite the relevance of these studies to demonstrate the importance of rabies as a cause of mortality in cattle, the description of the morbidity ratios of the outbreaks is fundamental for estimating the economic losses caused by the disease. This is evident in the present study; of 28 outbreaks diagnosed on farms with up to 500 cattle, 18 had morbidity ratios higher than $1 \%$, and of these, in six, it was higher than $5 \%$. When properties with more than 500 cattle were analyzed, in only five the morbidity ratio exceeded $1 \%$, and in no instance, this ratio was higher than 3\%.

The methodology used to estimate the economic losses due to bovine rabies-related deaths used in this study is similar to those used in other studies to estimate the economic losses caused by a specific disease in cattle (Heckler et al. 2018)

Another methodology used to estimate economic losses caused by a particular disease is the database from veterinary diagnostic laboratories - VDLs (Lima et al. 2005). In this approach, the percentage of $d$ cases of a particular disease in cattle diagnosed in a given VDL is calculated over the total number of diagnosis performed in cattle in that VDL and this 
percentage is extrapolated as the percentage of deaths caused by this disease in the region of the VDL. In a survey of bovine diseases carried out in Mato Grosso do Sul between 2008 and 2012 (Ribas et al. 2013), 15.92\% were cases of rabies. Considering that the annual mortality of cattle in Brazil is estimated at $5 \%$ and that the herd size of MS at the time of the study was 23 million cattle, then 183,080 of these would die from rabies. However, the data of the present study do not support this, since deaths attributed to rabies in almost seven years totaled 305 cattle. Such a discrepancy should not be expected in the face of the existence of an official bovine rabies control program in Brazil, which determines the compulsory notification of cases of the disease (Brasil 2009). However, this notification depends on the farmer's initiative; therefore, the accuracy of the methodologies used depends on the improvement of data collection by the official veterinary service.

Data on the losses caused by bovine rabies in other countries are also very imprecise. In Central and South America, the estimated loss for the disease is 100,000 to 500,000 cattle per year, but there is insufficient data to accurately determine these figures and fatality cases are estimated to be greater than the figures presented (Swanepoel 2004). There is a shortage of data on bovine rabies; in several countries where more accurate epidemiological information on canine rabies and rabies in wild animals, exist (Swanepoel 2004). An earlier study shows that in the Americas, the annual cattle loss varies from two to 32,200 animals, with an economic impact of US\$ 5,000 to US\$ 22 million (Acha \& Malaga-Alba 1968). The economic impact of the disease is also evaluated from public health, mainly the cost with pre and post-exposure treatment in humans.

The total cost of vaccination would be less than US $\$ 200.00$ in 45 of the 52 properties surveyed in the current report. When the cost of vaccination is compared to the losses caused by rabies-associated deaths, regardless of the size of the herd, the cost of the vaccination averaged $9.74 \%$ of the estimated economic loss, demonstrating that vaccination is an efficient and economically feasible procedure for rabies control. Although rabies vaccination is widely recommended in Brazil (Brasil 2009), there are not detailed reports on the efficiency of this procedure in the mitigation of the economic losses. In a study carried out in Mexico (Anderson et al. 2012), which compared the economic impact of bovine rabies-cost with two methods of its prevention, it was concluded that vaccination of cattle is more economically beneficial to the farmer than the control of vampire bats.

The data obtained in the present study demonstrate that the correct evaluation of the damages caused by rabies requires an adequate methodology based on the collection of individualized data on each occurrence of the disease. Considering that $43.57 \%$ of the MS cattle herd is in an area of risk for rabies, the morbidity ratios cannot be extrapolated to the total State herd.

The morbidity ratios can be higher than those described in the present study since our data considered deaths reported at the time of the outbreak, which is most likely lower than if the final outbreak data. The absence of standardization in data collection procedures is also a limiting factor for the elaboration of an efficient model for estimating the economic losses caused by bovine rabies.

\section{CONCLUSIONS}

Rabies is a cause of economic losses for the cattle industry in Mato Grosso do Sul. Vaccination is an economically feasible sanitary measure to minimize losses regardless of the size of the herd.

It is necessary to improve the efficiency in data collection by the rabies surveillance system in order to better evaluated the economic losses in the outbreaks.

Conflict of interest statement. - The authors declare that there are no conflicts of interest.

\section{REFERENCES}

Acha P.N. \& Malaga-Alba A. 1968. Economic losses due to Desmodus rotundus, p.207-214. In: Greenhall A.M. \& Schmidt U. (Eds), Natural History of Vampire Bats. CRC Press, Boca Raton.

Anderson A.M., Shwiff S.A., Gebhardt K., Ramırez A.J., Shwiff S., Kohler D. \& Lecuona L. 2012. Economic evaluation of vampire bat (Desmodus rotundus) rabies prevention in Mexico. Staff Publications 1091, USDA National Wildlife Research Center. Available at <http://digitalcommons.unl.edu/ icwdm_usdanwrc/1091> Accessed on Mar. 1, 2018.

Andrade J., Azevedo S., Peconick A.P., Pereira S., Barçante J., Vilar A.L. \& Silva M. 2014. Estudo retrospectivo da raiva no Estado da Paraíba, Brasil, 2004 a 2011. Braz. J. Vet. Res. Anim. Sci. 51(3):212-219. <http://dx.doi. org/10.11606/issn.1678-4456.v51i3p212-219>

Anyiam F., Lechenne M., Mindekem R., Oussigéré A., Naissengar S., Alfaroukh I.O., Mbilo C., Moto D.D., Coleman P.G., Probst-Hensch N. \& Zinsstag J. 2017. Cost-estimate and proposal for a development impact bond for canine rabies elimination by mass vaccination in Chad. Acta Tropica 175:112-120. <http://dx.doi.org/10.1016/j.actatropica.2016.11.005><PMid:27889225>

Barros C.S.L., Driemeier D., Dutra I.S. \& Lemos R.A.A. 2006. Rabies, p.21-28. In: Ibid. (Eds), Doenças do Sistema Nervoso de Bovinos no Brasil. Valée, Montes Claros.

Braga G.B., Grisi-Filho J.H.H., Leite B.M., Sena E.F. \& Dias R.A. 2014. Predictive qualitative risk model of bovine rabies occurrence in Brazil. Prev.Vet. Med. 113(4):536-546.<http://dx.doi.org/10.1016/j.prevetmed.2013.12.011> <PMid:24433635>

Brasil. 2009. Controle da Raiva dos Herbívoros: manual técnico. $2^{a}$ ed. Secretaria de Defesa Agropecuária, Ministério da Agricultura, Pecuária e Abastecimento, Brasília. 124p.

CEPEA 2017. Centro de Estudos Avançados em Economia Aplicada. Available at <http://www.cepea.esalq.usp.br/br/indicador/boi-gordo.aspx> Accessed on Mar. 1, 2018.

Dhankhar P., Vaidya S.A., Fishbien D.B. \& Meltzer M.I. 2008. Cost effectiveness of rabies post exposure prophylaxis in the United States. Vaccine 26(33):4251-4255. <http://dx.doi.org/10.1016/j.vaccine.2008.05.048> <PMid:18599167>

Dognani R., Pierre E.J., Silva M.C.P., Patrício M.A.C., Costa S.C., Prado J.R. \& Lisbôa J.A.N. 2016. Epidemiologia descritiva da raiva dos herbívoros notificados no estado do Paraná entre 1977 e 2012. Pesq. Vet. Bras. 36(12):1145-1154. <http://dx.doi.org/10.1590/s0100-736x2016001200001>

Hampson K., Coudeville L., Lembo T., Sambo M., Kieffer A., Attlan M., Barrat J., Blanton J.D., Briggs D.J., Cleaveland S., Costa P., Freuling C.M., Hiby E., Knopf L., Leanes F., Meslin F.X., Metlin A., Miranda M.E., Müller T., Nel L.H., Recuenco S., Rupprecht C.E., Schumacher C., Taylor L., Vigilato M.A., Zinsstag J. \& Dushoff J. 2015. Estimating the global burden of endemic canine rabies. PLoS Negl. Trop. Dis. 9(4):e0003709. <http://dx.doi.org/10.1371/journal. pntd.0003709><PMid:25881058>

Heckler R.F., Lemos R.A.A., Gomes D.C., Dutra I.S., Silva R.O.S., Lobato F.C.F., Ramos C.A.N. \& Brumatti R.C. 2018. Blackleg in cattle in the state of Mato 
Grosso do Sul, Brazil: 59 cases. Pesq. Vet. Bras. 38(1):6-14. <http://dx.doi. org/10.1590/1678-5150-pvb-4964>

Heinemann M.B., Fernandes-Matioli F.M.C., Cortez A., Soares R.M., Sakamoto S.M., Bernardi F., Ito F.H., Madeira A.M.B.N. \& Richtzenhain L.J. 2002. Genealogical analyses of rabies virus strains from Brazil based on $\mathrm{N}$ gene alleles. Epidemiol. Infect. 128(3):503-511. <http://dx.doi.org/10.1017/ S095026880200688X><PMid:12113496>

IBGE 2016. Tabela 3939, efetivo de rebanhos. Sistema IBGE de Recuperação Automática (SIDRA), Intituto Brasileiro de Geografia e Estatística. Available at <https://sidra.ibge.gov.br/tabela/3939\#resultado> Accessed on Mar. $1,2018$.

King A.A. \& Turner G.S. 1993. Rabies: a review. J. Comp. Pathol. 108(1):1-39. <http://dx.doi.org/10.1016/S0021-9975(08)80224-1><PMid:8473555>

Knobel D.L., Cleaveland S., Coleman P.G., Fèvre E.M., Meltzer M.I., Miranda M.E., Shaw A., Zinsstag J. \& Meslin F.X. 2005. Re-evaluating the burden of rabies in Africa and Asia. Bull. World Health Org. 83(5):360-368. <PMid:15976877>

Kotait I., Gonçalves C.A., Peres N.F., Souza M.C.A.M. \& Tarqueta M.C. 1998. Controle da Raiva dos Herbívoros: manual 1. Instituto Pasteur, São Paulo. 15p.

Langohr I.M., Irigoyen L.F., Lemos R.A.A. \& Barros C.S.L. 2003. Aspectos epidemiológicos, clínicos e distribuição das lesões histológicas no encéfalo de bovinos com raiva. Ciência Rural 33(1):125-131. <http://dx.doi. org/10.1590/S0103-84782003000100020>

Lemos R. 2005. Enfermidades do sistema nervoso de bovinos de corte das Regiões Centro-Oeste e Sudeste do Brasil. Doctoral Dissertation, Faculdade de Ciências Agrárias e Veterinárias, Universidade Estadual Paulista, Jaboticabal, SP. 149p.

Lima E.F., Riet-Correa F., Castro R.S., Gomes A.B. \& Lima F.S. 2005. Sinais clínicos, distribuição das lesões no sistema nervosos e epidemiologia da raiva em herbívoros na região Nordeste do Brasil. Pesq. Vet. Bras. 25(4):250-264. <http://dx.doi.org/10.1590/S0100-736X2005000400011>

Marcolongo-Pereira C., Sallis E.S.V., Grecco F.B., Raffi M.B., Soares M.P. \& Schild A.L. 2011. Raiva em bovinos na Região Sul do Rio Grandedo Sul: epidemiologia e diagnóstico imuno-histoquímico. Pesq. Vet. Bras. 31(4):331335. <http://dx.doi.org/10.1590/S0100-736X2011000400010>

Meltzer M.I. \& Rupprecht C.E. 1998. A review of the economics of the prevention and control of rabies. Part 2: rabies in dogs, livestock and wildlife. Pharmacoeconomics 14(5):481-498. <http://dx.doi.org/10.2165/00019053199814050-00003><PMid:10344914>

Mori A.E. \& Lemos R.A.A. 1998. Raiva, p.47-58. In: Ibid (Eds), Principais Enfermidades de Bovinos de Corte do Mato Grosso do Sul: reconhecimento e diagnóstico. Universidade Federal de Mato Grosso do Sul, Campo Grande, MS.
Oliveira M.S., Frota F.P., Carvalho M.P., Bersano P.R.O., Dias F.E.F., Cavalcante T.V., Santos H.D. \& Minharro S. 2013. Frequência da raiva em herbívoros e humanos no estado do Tocantins de 1999 a 2010: relatório técnico. Acta Vet. Bras. 7(3):180-183.

Ribas N.L.K.S., Carvalho R.I., Santos A.C., Valençoela R.A., Gouveia A.F., Castro M.B., Mori A.E. \& Lemos R.A.A. 2013. Doenças do sistema nervoso de bovinos no Mato Grosso do Sul: 1082 casos. Pesq.Vet. Bras. 33(10):1183-1194 <http://dx.doi.org/10.1590/S0100-736X2013001000003>

Rupprecht C.E., Hanlon C.A. \& Hemachudha T. 2002. Rabies re-examined. Lancet Infect. Dis. 2(6):327-343. <http://dx.doi.org/10.1016/S14733099(02)00287-6><PMid:12144896>

Sanches A.W.D., Langohr I.M., Stigger A.L. \& Barros C.L.S. 2000. Doenças do sistema nervoso central em bovinos no Sul do Brasil. Pesq. Vet. Bras. 20(3):113-118. <http://dx.doi.org/10.1590/S0100-736X2000000300005>

Shwiff S.A., Sterner R.T., Jay M.T., Parikh S., Bellomy A., Meltzer M.I., Rupprecht C.E. \& Slate D. 2007. Direct and indirect costs of rabies exposure: a retrospective study in Southern California (1998-2002). J. Wildl. Dis. 43(2):251-257. <http://dx.doi.org/10.7589/0090-3558-43.2.251><PMid:17495309>

Silva A.C.R., Caporale G.M.M., Gonçalves C.A., Targueta M.C., Comin F., Zanetti C.R. \& Kotait I. 2000. Antibody response in cattle after vaccination with inactivated and attenuatedrabies vaccines. Revta Inst. Med. Trop. S. Paulo 42(2):95-98. <http://dx.doi.org/10.1590/S0036-46652000000200006>

Silva J.A., Moreira E.C., Haddad J.P.A., Modena C.M. \& Tubaldini M.A.S. 2001 Distribuição temporal e espacial da raiva bovina em Minas Gerais, 1976 a 1997. Arq. Bras. Med. Vet. Zoot. 53(3):263-272.<http://dx.doi.org/10.1590/ S0102-09352001000300001>

Sterner R.T., Meltzer M.I., Shwiff S.A. \& Slate D. 2009. Tactics and economics of wildlife oral rabies vaccination, Canada and the United States. Emerg. Infect. Dis. 15(8):1176-1184. <http://dx.doi.org/10.3201/eid1508.081061> <PMid:19757549>

Swanepoel R. 2004. Rabies, p.1123-1182. In: Coetzer J. A. W., Tustin R.C. (Eds), Infectious Diseases of Livestock. Vol.2. 2nd ed. Oxford University Press, Cape Town.

Taylor L.H. \& Knopf L. 2015. Surveillance of human rabies by national authorities, a global survey. Zoonoses Public Health 62(7):543-552. <http:// dx.doi.org/10.1111/zph.12183><PMid:25683444>

Teixeira T.F., Holz C.L., Caixeta S.P.M.B., Dezen D., Cibulski S.P., Silva J.R., Rosa J.C.A., Schmidt E., Ferreira J.C., Batista H.B.C.R., Caldas E., Franco A.C. \& Roehe P.M. 2008. Diagnóstico de raiva no Rio Grande do Sul, Brasil, de 1985 a 2007. Pesq. Vet. Bras. 28(10):515-520. <http://dx.doi.org/10.1590/ S0100-736X2008001000012>

Thrusfield M.V. 2004. Descrevendo a ocorrência de doenças, p.47-73. In: Ibid. (Ed), Epidemiologia Veterinária. Roca, São Paulo. 